\title{
ANALISIS KARAKTERISTIK PERUSAHAAN TERHADAP TINGKAT DISCLOSURE LAPORAN KEUANGAN
}

\author{
Ustman ${ }^{1}$, Subhan ${ }^{2}$ \\ 1,2Universitas Madura, Indonesia \\ Email: ${ }^{1}$ ustman@unira.ac.id
}

\begin{abstract}
The purpose this study is to empirically examine the characteristics of companies on the level of disclosure financial statements. Disclosure financial statements is very important for shareholders and creditors to assess the quality of a company's accounting information. So transparency is needed from management to give trust to stakeholders. There are four characteristics of a company that can affect the level of disclosure of financial statements, namely liquidity, leverage, profitability and firm size. The number of samples used in this study were 43 manufacturing companies listed on the Indonesia Stock Exchange. Data analysis uses multiple linear regression. The results obtained showed that the variables of liquidity, leverage, profitability and firm size do not affect the level of disclosure financial statements. The implication of the research result is that report disclosure is an obligation in every report so it is not appropriate if it is related to company characteristics.
\end{abstract}

Keywords: disclosure of financial statements, liquidity, leverage, profitability, firm size

\section{ABSTRAK}

Tujuan penelitian ini untuk menguji secara empiris karakteristik perusahaan terhadap tingkat disclosure laporan keuangan. Disclosure laporan keuangan sangat penting untuk para shareholders dan kreditur untuk menilai kualitas informasi akuntansi suatu perusahaan. Maka diperlukan transparansi dari manajemen untuk memberikan kepercayaan kepada stakeholders. Ada empat karakteristik perusahaan yang dapat mempengaruhi tingkat disclosure laporan keuangan yaitu likuiditas, leverage, profitabilitas dan ukuran perusahaan. Jumlah sampel yang digunakan dalam penelitian ini sebanyak 43 perusahaan manufaktur yang terdaftar di Bursa Efek Indonesia. Analisis data menggunakan regresi linier berganda. Hasil penenlitian menunjukkan bahwa variabel likuiditas, leverage, profitabilitas dan ukuran perusahaan tidak berpengaruh terhadap tingkat disclosure laporan keuangan. Implikasi hasil penelitian adalah bahwa pengungkapan laporan merupakan kewajiban dalam setiap pelaporan sehingga tidak sesuai jika dikaitkan dengan karakteristik perusahaan.

Kata kunci: disclosure laporan keuangan, likuiditas, leverage, profitabilitas, ukuran perusahaan

\section{KETERANGAN ARTIKEL}

Riwayat Artikel: diterima: 5 Januari 2020; direvisi: 1 April 2020; disetujui: 23 Mei 2020

Klasifikasi JEL: M41

Cara Mensitasi: Ustman dan Subhan. (2020). Analisis Karakteristik Perusahaan terhadap Tingkat Disclosure Laporan Keuangan. JIAFE (Jurnal Ilmiah Akuntansi Fakultas Ekonomi), 6(1), 71-82. https://doi.org/10.34204/jiafe.v6i1.1665

Copyright@2020. JIAFE (Jurnal Ilmiah Akuntansi Fakultas Ekonomi) Universitas Pakuan

\section{PENDAHULUAN}

Perusahaan dianjurkan untuk memberikan transparansi laporan keuangan sesuai karakteristik umum dalam Standar Akuntansi Keuangan (SAK) yaitu menyajikan secara wajar relevansi dan transparansi laporan posisi keuangan, laporan laba rugi komprehensif, ekuitas dan arus kas suatu entitas. Penyajian wajar mensyaratkan penyajian secara jujur dampak dari transaksi, kejadian dan kondisi 
luar biasa sesuai dengan definisi dan kriteria pengakuan maupun pengungkapan aset, liabilitas, ekuitas, pendapatan dan beban yang diatur dalam kerangka dasar penyusunan dan penyajian laporan keuangan. Pengungkapan laporan keuangan merupakan bentuk pertanggungjawaban perusahaan kepada manajer, yang berguna untuk memudahkan pengambilan keputusan usaha yang paling produktif.

Berdasarkan penelitian Hilmi (2010), banyak penelitian yang mengukur ketaatan dibandingkan dengan pengungkapan laporan keuangan. pengungkapan dalam penelitian ini merupakan pengungkapan wajib yang harus ada dan wajib dalam SAK. Hasil penelitian sebelumnya mengenai ting disclosure laporan keuangan yang telah dilakukan skala nasional dan internasional masih menunjukkan hasil yang ebrbeda-beda (Patrick, 2007; Lesmana, 2010; Yulianingtyas, 2011; Fitri 2011; Sembiring, 2012; dan Khasanah dan Rahardjo, 2014), sehingga perlu penelitian lanjutan menguji gap dari hasil penelitian.

Proses pembuatan laporan tahunan merujuk dari penelitian mengenai kelengkapan pengungkapan (disclosure) dalam laporan tahunan dan masalah yang mempengaruhinya. Laporan keuangan merupakan hasil akhir dari catatan akuntansi yang dapat digunakan sebagai informasi untuk berkomunikasi antara data keuangan atau aktivitas suatu perusahaan dengan pihak yang berkepentingan misalnya manajer, investor, dan kreditur.

Pasar modal dapat mendukung perkembangan ekonomi, karena mengalokasikan dana dari sektor yang tidak produktif ke sektor yang produktif. Pasar modal dapat memperkuat perekonomian dengan memberikan modal kepada perusahaan yang telah go public. Kondisi ekonomi sekarang telah berubah dan memberi banyak pengaruh pada dunia usaha sehingga stakeholders lebih berhati-hati dalam menanamkan modalnya. Perekonomian yang tidak stabil menyebabkan stakeholders lebih berhati-hati dalam menanamkan modalnya karena pasar modal memiliki risiko yang tinggi. Maka perlu adanya transparansi dari manajemen dalam memberikan informasi yang lengkap dan wajar pada perusahaannya, sehingga dapat memberikan kepercayaan kepada pengambil keputusan dalam mengantisipasi perubahan ekonomi (Suwito \& Herawaty, 2005; Sembiring, 2012).

$$
\text { Jensen dan Meckling (1976) }
$$

mencetuskan teori keagenan yamg menganggap ada asimetri informasi antara principal dan agent. Principal dinyatakan sebagai pemegang saham dan manajemen sebagai agent. Principal memberikan fasilitas berupa dana yang ditanamkan untuk menjalankan perusahaan, dan agent sebagai manajemen yang menjalankan atau mengelola perusahaan. Agent diwajibkan memberikan pertanggung jawaban atas usaha yang dikelolanya berupa laporan keuangan kepada principal. Sehingga informasi berupa laporan keuangan merupakan sarana akuntabilitas yang wajib diberikan manajemen kepada pemegang saham.

Keputusan investasi dipengaruhi oleh kualitas laporan keuangan tahunan yang dikeluarkan oleh perusahaan. Dalam kualitas informasi keuangan terkandung dua jenis pengungkapan (disclosure) yang diterbitkan oleh entitas. Pengungkapan pertama, pengungkapan wajib (mandatory disclosure) merupakan pengungkapan yang diwajibkan peraturan pemerintah dan pengungkapan kedua, pengungkapan sukarela (voluntary disclosure) merupakan pengungkapan yang tidak diwajibkan peraturan. Konsep mengenai luas pengungkapan laporan keuangan yaitu adequate disclosure, fair disclosure, dan full disclosure. Konsep yang paling sering digunakan adalah adequate disclosure (pengungkapan cukup), dilakukan pengungkapan minim yang disyaratkan oleh peraturan yang berlaku dimana pada tingkat ini investor dapat menginterpretasikan angkaangka dalam laporan keuangan. 
Peneliti tertarik melakukan pengujian secara empiris mengenai pengaruh karakteristik perusahaan terhadap tingkat disclosure laporan keuangan pada perusahaan manufaktur di Bursa Efek Indonesia. Karena karakteristik perusahaan merupakan ciri-ciri khusus yang melekat pada perusahaan dan memiliki karakteristik yang berbeda satu entitas dengan entitas yang lainnya. Pengungkapan (disclosure) atas laporan keungan dapat dipengaruhi oleh tingkat likuiditas, tingkat leverage, tingkat profitabilitas, dan ukuran perusahaan. Alasan peneliti menguji karakteristik perushaan juga ingin mengetahui tingkat laporan keuangan pertanggungjawaban sosial yang diungkapkan oleh perusahaan.

\section{KAJIAN LITERATUR DAN PENGEMBANGAN HIPOTESIS}

Penelitian mengenai kelengkapan pengungkapan laporan keuangan dan hal yang mempengaruhinya menjadi sesuatu menarik bagi calon stakeholders, pembuat kebijakan dalam menilai kualitas akuntansi suatu perusahaan. Menurut Imhoff (2003) dalam penelitiannya ia menawarkan rekomendasi spesifik untuk mengatasi masalah saat ini yang dirancang untuk meningkatkan kualitas dan integritas lingkungan pelaporan keuangan. kualitas akuntansi yang tinggi akan memberikan tingkat pengungkapan pelaporan yang baik. Sedangkan kelengkapan pengungkapan laporan keuangan dapat dipengaruhi oleh karakteristik perusahaan.

Penelitian sebelumnya meneliti faktor yang mempengaruhi kelengkapan pengungkapan laporan keuangan perusahaan manufaktur di Bursa Efek sebanyak 34 perusahaan pada periode tahun 2002. Variabel penelitian menggunakan leverage, likuidity, solvability, ukuran perusahaan dan penerbitan sekuritas. Hasilnya penelitian menunjukkan ukuran perusahaan dan penerbitan sekuritas mempengaruhi kelengkapan pengungkapan laporan keuangan. selain dua variabel tersebut tidak menunjukkan pengaruh terhadap kelengkapan pengungkapan laporan keuangan (Simanjuntak \& Widiastuti, 2004). Sedangkan Sudarmadji dan Sularto (2007), menguji ukuran perusahaan, profitabilitas, leverage dan tipe kepemilikan perusahaan pada luas voluntary disclosure dengan sampel 8 perusahaan manufaktur. Hasil penelitian yang didapat tidak ada satu variabel yang berpengaruh terhadap luas voluntary disclosure laporan keuangan.

Rasio Likuidtas jika dilihat dari sudut pandang kreditur, rasio lancar yang levelnya lebih tinggi dapat menjadikan perlindungan terhadap kemungkinan tidak stabilnya ekonomi hingga terjadi kegagalan perusahaan (Santioso \& Yenny, 2012). Aktiva lancar dengan nilai lebih besar atas kewajiban jangka pendek dapat membantu melindungi klaim jika terjadi kegagalan perusahaan, karena aset lancar dapat dicairkan dengan pelelangan atau tidak terdapat penagihan piutang yang tinggi. Aktiva lancar perusahaan dapat dijadikan sebagai alat pengukur kemampuan entitas untuk memenuhi kewajiban jangka pendeknya. Tingkat likuiditas yang tinggi dapat menunjukkan kuatnya kondisi keuangan entitas. Entitas dengan tingkat likuiditas tinggi cenderung untuk melakukan pengungkapan informasi yang lebih luas kepada pihak luar karena ingin menunjukkan bahwa entitas itu kredibel.

Tingkat likuiditas yang tinggi menunjukkan kuatnya kondisi keuangan perusahaan. Perusahaan dengan tingkat rasio likuiditas tinggi cenderung untuk melakukan pengungkapan informasi yang lebih luas kepada pihak luar karena ingin menunjukkan bahwa perusahaan itu kredibel dan untuk membedakan dari perusahaan lain yang mengalami rasio likuiditas yang lebih rendah (Albitar, 2015). Di sisi lain, teori agensi berpendapat bahwa perusahaan dengan persentase likuiditas yang rendah mengungkapkan lebih banyak informasi untuk 
mengurangi konflik antara pemegang saham dan kreditur (Abd-Elsalam, 1999). Berdasarkan uraian tersebut, maka dapat dikembangkan hipotesis sebagai berikut:

\section{$\mathrm{H}_{1}$ : likuiditas berpengaruh positif terhadap disclosure laporan keuangan.}

Leverage merupakan pengukuran besarnya aktiva yang dibiayai dengan liabilitas, baik liabilitas jangka pendek maupun liabilitas jangka panjang atau kenaikan apabila terus likuidasi (Santioso \& Yenny, 2012). Penggunaan liabilitas yang besar dalam perusahaan mengharuskan membuat perusahaan menyediakan informasi yang banyak untuk memenuhi tuntutan shareholders dan kreditur, karena kreditur akan selalu mengawasi dana yang dipinjamkannya kepada entitas. Pada teori agency, leverage yang lebih tinggi akan mengungkapkan lebih banyak informasi karena agency cost entitas dengan struktur ekuitas seperti itu juga lebih tinggi.

Perusahaan akan lebih terdorong untuk melakukan pengungkapan laporan keuangan lebih tinggi apabila memiliki rasio leverage yang tinggi karena memiliki tujuan untuk memenuhi kebutuhan informasi kreditur (Sriayu \& Mimba, 2013). Leverage dapat mempengaruhi tingkat pengungkapan sukarela. Misalnya rasio leverage yang tinggi dapat meningkatkan kebijakan pengungkapan untuk manajer dan mendorong mereka untuk mengungkapkan lebih banyak informasi untuk memenuhi minat investor di sisi lain, rasio yang rendah dapat mendorong manajer untuk mengarahkan prosedur pengungkapan mereka kepada pemegang saham lebih dari kreditur (Albitar, 2015). Oleh karena itu, manajer termotivasi untuk mengungkapkan lebih banyak data dalam laporan keuangan perusahaan untuk menurunkan biaya dan untuk menghindari klaim kreditur. Dari hasil uraian tersebut, maka dapat dikembangkan hipotesis sebagai berikut:

$\mathrm{H}_{2}$ : leverage berpengaruh positif terhadap disclosure laporan keuangan.
Profitabilitas merupakan indikator kinerja yang dilakukan manajemen untuk mengelola kekayaan entitas yang ditunjukkan oleh profit yang dihasilkan. Profitabilitas dianggap menjadi tolok ukur pengembalian investasi atau profit return, semakin tinggi profitabilitas maka semakin besar pengungkapan informasi laporan keuangan. Santioso dan Yenny (2012) menjelaskan profitability memberikan kemampuan entitas untuk memperoleh profit melalui kemampuan dan sumber daya yang ada seperti transaksi penjualan, kas, ekuitas dan sebagainya. Profitabilitas pada penelitian ini menggunakan return on equity.

Ada sebuah proposisi umum bahwa kesediaan perusahaan untuk mengungkap informasi secara positif terkait dengan profitabilitasnya. Satu motif untuk ini dapat diturunkan dari teori keagenan. Disarankan agar manajer perusahaan yang memperoleh keuntungan untuk mengungkap informasi yang luas untuk menunjukkan dan menjelaskan kepada pemegang saham bahwa mereka bertindak demi kepentingan terbaik dan membenarkan perolehan kompensasi mereka. Penelitian sebelumnya menggunakan ukuran profitabilitas yang berbeda seperti return on total asset dan return on equity (Albitar, 2015). Menurut Kamil dan Herusetya (2012), tingkat profitabilitas yang tinggi dapat mencerminkan kemampuan perusahaan untuk menghasilkan laba dan meningkatkan tanggung jawab dalam mengungkapkan laporan keuangan. Pada penelitian Sriayu dan Mimba (2013) hasilnya profitabilitas tidak berpengaruh signifikan terhadap pengungkapan Corporate Social Responsiility. Maka dari adanya perbedaan hasil penelitian dapat dikembangkan hipotesis sebagai berikut:

$\mathrm{H}_{3}$ : profitabilitas berpengaruh positif terhadap disclosure laporan keuangan.

Ukuran perusahaan merupakan skala yang memiliki fungsi untuk mengklasifikasikan besar kecilnya suatu entitas bisnis. Skala 
ukuran perusahaan dapat menjadi pengaruh luas tidaknya pengungkapan informasi dalam laporan keuangan. Menurut Daud (2017) perusahaan yang telah go public cenderung mengungkapkan informasi sosial atau tanggung jawab sosial lebih banyak dari pada perusahaan yang belum go public. Sudarmadji dan Sularto (2007) menyatakan ukuran perusahaan dapat dilihat dari total aktiva, penjualan dan kapitalisasi pasar. Semakin besar total aktiva, penjualan dan kapitalisasi pasar maka semakin besar ukuran perusahaan tersebut. Ketiga variabel ini dapat digunakan untuk menentukan ukuran perusahaan karena dapat mewakili besarnya entitas tersebut. Semakin besar total aktiva, maka semakin banyak modal yang ditanam. Semakin banyak penjualan, maka semakin banyak cash flow dan semakin besar kapitalisasi pasar. Dari ketiga pengukuran ukuran perusahaan, total aktiva menjadi yang terbaik karena dinilai relatif lebih stabil dibandingkan dengan nilai market capitalized dan penjualan dalam mengukur ukuran perusahaan. Hipotesis pada umumnya menjelaskan bahwa praktik pengungkapan laporan keuangan perusahaan berpengaruh positif dengan ukuran perusahaan. Salah satu alasan ukuran perusahaan dapat berpengaruh positif terhadap pengungkapan laporan keuangan perusahaan berasal dari teori agensi. Jensen dan Meckling (1976) telah mengkonfirmasi bahwa biaya agensi cenderung meningkat dengan proporsi modal saham. Mengingat bahwa proporsi modal saham cenderung lebih tinggi untuk perusahaan besar, masuk akal untuk berspekulasi bahwa perusahaan besar lebih cenderung memberikan lebih banyak informasi dalam upaya mengurangi biaya agensi. Zadeh dan Eskandari (2012) meneliti bahwa karakteristik perusahaan seperti ukuran perusahaan memiliki kualitas dan kuantitas yang berbeda untuk berbagai negara. Namun, sebagian besar studi menemukan hubungan positif antara ukuran perusahaan dan tingkat pengungkapan risiko serta ukuran perusahaan dapat mempengaruhi tingkat pengungkapan risiko. Dari hasil uraian tersebut, maka dapat dikembangkan hipotesis sebagai berikut:

$\mathrm{H}_{4}$ : total aset berpengaruh positif terhadap disclosure laporan keuangan.

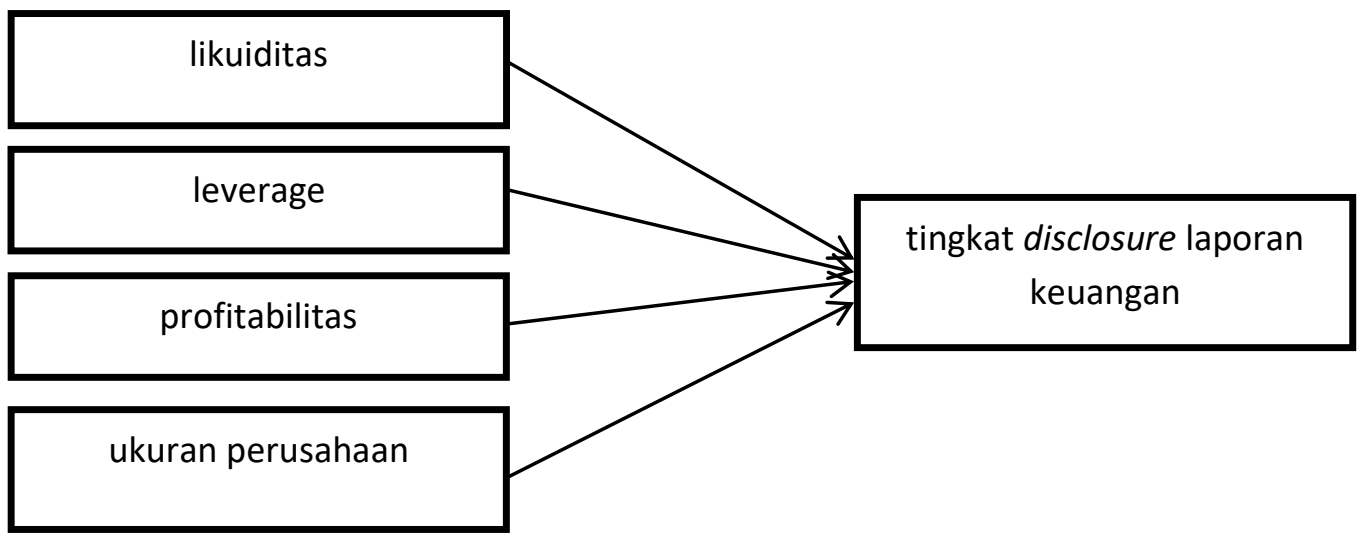

Gambar 1

Kerangka Pemikiran

\section{METODE PENELITIAN}

Jenis penelitian ini menggunakan jenis penelitian dekskriptif kuantitatif. Objek penelitian ini diambil dari perusahaan yang terdaftar di Bursa Efek Indonesia (BEI) pada periode 2016 sampai 2018 menggunakan 
sumber data sekunder yang telah di dokumentasikan.

Populasi penelitian yaitu seluruh perusahaan manufaktur yaitu berjumlah 162 perusahaan. Teknik penentuan sampel menggunakan metode purposive sampling dengan tujuan dan kriteria (1) menggunakan mata uang rupiah, (2) yang selalu listing di BEI di periode 2016-2018, (3) yang laporan keuangannya lengkap dengan mengungkapkan tanggung jawab sosial dari tahun 2016-2018, dan (4) perusahaan selalu profit selama tahun 2016-2018. Jumlah sampel diperoleh sebanyak 43 perusahaan yang telah memenuhi kriteria pada masing-masing periode.

Metode yang digunakan dalam penelitian ini adalah regresi linier berganda. Penelitian ini menggunakan empat variabel bebas yaitu likuiditas, leverage, profitabilitas dan ukuran perusahaan. Likuiditas diukur dengan current ratio yang dirumuskan dengan:

$$
\begin{aligned}
& \text { Current ratio } \\
& =\frac{\text { Aset lancar }}{\text { Liabilitas jangka pendek }}
\end{aligned}
$$

Leverage diukur menggunakan Debt To Equity Ratio (DER) dimana rasio yang menghitung bagian dari keseluruhan kebutuhan dana yang dibiayai liabilitas. Penggunaan liabilitas yang besar pada entitas akan membuat entitas menyediakan informasi lebih banyak untuk memenuhi permintaan investor dan kreditor, karena kreditor selalu mengawasi dana yang dipinjamkannya kepada perusahaan.

$$
\text { Debt to equity ratio }=\frac{\text { Total utang }}{\text { Equitas }}
$$

Return On Equity (ROE) merupakan pengukuran atas kinerja perusahaan didalamnya termasuk imbalan hasil atau ekuitas. Pengukuran ini membandingkan laba bersih setelah pajak dengan ekuitas yang telah di investasikannya pemegang saham di entitas. Pengukuran merupakan yang paling baik pada suatu entitas akan mendorong para manajer untuk memberikan informasi yang lebih terinci, karena para investor kebanyakan lebih menyukai entitas dengan profit yang tinggi. Mereka beranggapan jika profitabilitas tinggi entitas mampu memberikan pengembalian investasi yang tinggi pula, sehingga semakin tinggi tingkat profitabilitas perusahaan maka semakin besar pengungkapan informasinya.

$$
\text { Return on equity }=\frac{\text { Laba bersih }}{\text { Total equitas }}
$$

Mengukur ukuran perusahaan dapat dinilai dari total aset yang dimiliki perusahaan. Pengukuran menggunakan Logaritma natural (Ln) dari total aset perusahaan. Variabel dependen dalam penelitian ini adalah pengungkapan Laporan Keuangan. Variabel ini mengukur berapa banyak pengungkapan laporan keuangan yang material diungkap oleh perusahaan. Dengan mengacu pada Peraturan Otoritas Jasa Keuangan tentang kelengkapan laporan tahunan emiten atau perusahaan publik. Dalam melakukan perhitungan angka indeks, peneliti menggunakan instrument angka indeks maksimum yaitu dengan membagi jumlah butir pengungkapan yang terpenuhi dengan jumlah semua butir pengungkapan yang mungkin dipenuhi. Angka indeks maksimum adalah satu. Perusahaan yang memiliki angka indeks satu menunjukkan bahwa telah melakukan pengungkapan laporan keuangan perusahaan manufaktur secara penuh.

Teknik analisis data yang digunakan dalam penelitian menggunakan analisis linier berganda, namun sebelum dilakukan pengujian terlebih dahulu melakukan uji asumsi klasik yang terdiri dari uji normalitas, multikolinieritas, heterokedastisitas dan autokolerasi. Model persamaan yang digunakan dalam penelitian ini adalah sebagai berikut: 
$Y=\alpha+b_{1} X_{1}+b_{2} X_{2}+b_{3} X_{3}+b_{4} X_{4}+e$

Keterangan :

$\mathrm{Y}=$ Disclosure Laporan Keuangan

$\alpha=$ Konstanta tetap

$b_{1}-b_{4}=$ Koefisien Regresi

$\mathrm{X}_{1} \quad=$ Current Ratio

$\mathrm{X}_{2} \quad=$ Debt to Equity Ratio

$\mathrm{X}_{3} \quad=$ Return On Equity Ratio

$\mathrm{X}_{4} \quad=$ Total Aset

$\mathrm{e} \quad=$ Standart Eror

\section{HASIL DAN PEMBAHASAN}

\section{Hasil Uji Statistik Deskriptif}

Berikut tabel hasil pengujian statistik deskriptif penelitian ini. Berdasarkan tabel 1 dapat diketahui informasi dari setiap variable mengenai nilai minimum, nilai maksimum, nilai rata-rata (mean), serta standart deviasi (ukuran sebaran statistik yang lazim) dari responden keseluruhan.

Tabel 1. Statistik Deskriptif

\begin{tabular}{lcccc}
\hline Variabel & Minimum & Maximum & Mean & Std. Deviation \\
\hline Likuiditas & 2.39 & 30.46 & 8.4060 & 5.71077 \\
Leverage & .61 & 6.29 & 2.5435 & 1.31061 \\
Profitabilitas & .01 & 2.25 & .4323 & .36211 \\
Ukuran Perusahaan & 21.67 & 37.96 & 31.5505 & 4.62624 \\
Tingkat Disclosure & 2.49 & 2.77 & 2.6307 & .06617 \\
\hline
\end{tabular}

Sumber: Data diolah

Dari statistik deskriptif dapat dilihat bahwa variable pertama yaitu likuiditas yang diukur current ratio memiliki nilai minimum 2,39 dan nilai maksimum 30,46 , hal ini berarti bahwa nilai data keuangan dari 43 perusahaan nilai terendah adalah 2,39 dan nilai tertinggi 30,46 dengan nilai rata-rata 8,40 dengan standart deviasi 5,71.

Variable kedua yaitu leverage yang diukur menggunakan Debt To Equity Ratio memiliki nilai minimum 0,61dan nilai maksimum 6,29, hal ini berarti bahwa nilai data keuangan dari 43 perusahaan nilai terendah adalah 0,61 dan nilai tertinggi 6,29 dengan nilai rata-rata 2,54 dengan standart deviasi 1,31. Variable profitabilitas diukur dengan Return On Equity Aset memiliki nilai minimum 0,01 dan nilai maksimum 0,25, hal ini berarti bahwa total data keuangan dari 43 perusahaan nilai terendah adalah 0,01 dan nilai tertinggi 0,25 dengan nilai rata-rata 0,43 dengan standart deviasi 0,36 . Total Aset memiliki nilai minimum 21,67 dan nilai maksimum 37,96, hal ini berarti bahwa total data keuangan dari 43 perusahaan nilai terendah adalah 21,67 dan nilai tertinggi 37,96 dengan nilai rata-rata 31,55 dengan standart deviasi 4,62. Variable dependen yaitu pengungkapan laporan keuangan memiliki nilai minimum 2,49 dan nilai maksimum 2,77, hal ini berarti dengan nilai rata-rata 2,63 dengan standart deviasi 0,66.

\section{Regresi Linier Berganda}

Hasil regresi pada penelitian ini disajikan dalam tabel sebagai berikut. 
Tabel 2. Regresi Linier Berganda

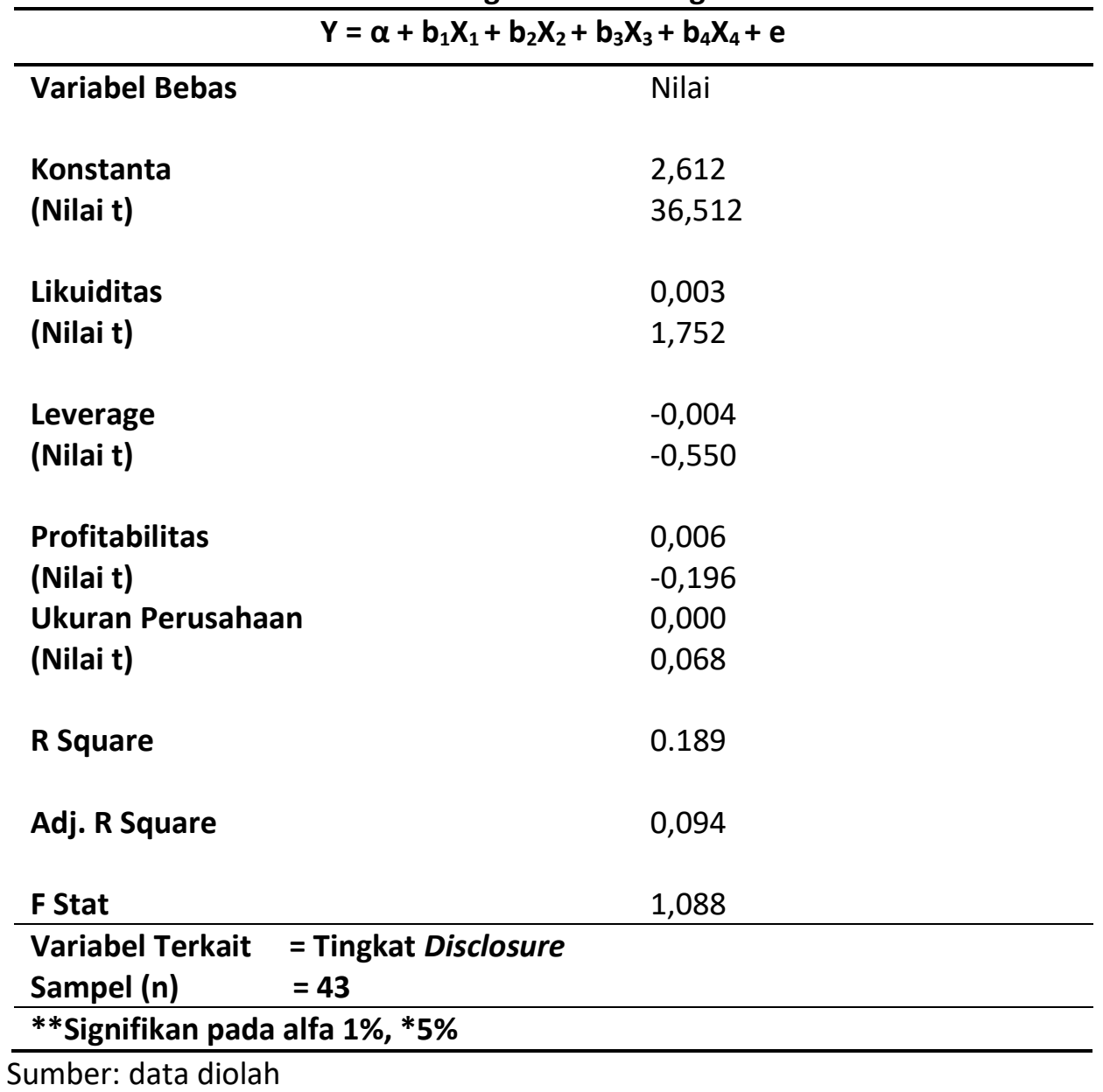

Berdasarkan analisis regresi pada tabel 2, dapat dijelaskan bahwa nilai signifikansi dari variabel likuiditas sebesar 0.088 lebih besar dari taraf signifikan 0,05 dengan nilai t hitung 1.752, yang menunjukkan bahwa tidak terdapat pengaruh signifikan variabel likuiditas terhadap tingkat disclosure laporan keuangan. $\mathrm{Hal}$ ini menunjukkan bahwa $\mathrm{H} 1$ ditolak. Jadi current ratio tidak berpengaruh signifikan terhadap pengungkapan laporan keuangan.

Hasil pengujian data rasio leverage terhadap tingkat disclosure laporan keuangan pada tabel 2, nilai signifikansi dari variabel leverage sebesar 0.585 dengan nilai t hitung .550 lebih kecil dari t table sebesar 1,682. Jika nilai signifikansi dari nilai $t$ hitung tersebut lebih besar dari 0.05 yaitu 0,585, maka akan dinyatakan tidak berpengaruh signifikan yang menunjukkan bahwa tidak terdapat pengaruh variabel independen debt to equity ratio terhadap disclosure laporan keuangan. Hal ini menunjukkan bahwa $\mathrm{H} 2$ ditolak.

Berdasarkan hasil pengujian data variabel return on equity ratio terhadap tingkat disclosure laporan keuangan pada tabel 2 yang menjadi variabel ketiga dalam penelitian ini, nilai signifikansi dari variabel return on equity ratio sebesar 0.846 dengan nilai $\mathrm{t}$ hitung 0,196 lebih kecil dari $\mathrm{t}$ table sebesar 1,682 . Jika nilai signifikansi dari nilai $t$ hitung tersebut lebih besar dari 0.05 yaitu 0,846, maka akan dinyatakan tidak berpengaruh signifikan yang menunjukkan bahwa tidak terdapat pengaruh return on equity ratio terhadap disclosure laporan keuangan. Hal ini menunjukkan bahwa H3 ditolak. 
Berdasarkan hasil pengujian data variabel total asset terhadap variabel dependen pengungkapan laporan keuangan pada tabel 2 yang menjadi variabel ketiga dalam penelitian ini, nilai signifikansi dari variabel return on equity ratio sebesar 0.946 dengan nilai $t$ hitung 0,068 lebih kecil dari $t$ table sebesar 1,682. Jika nilai signifikansi dari nilai $\mathrm{t}$ hitung tersebut lebih besar dari 0.05 yaitu 0,946, maka akan dinyatakan tidak berpengaruh signifikan yang menunjukkan bahwa tidak terdapat pengaruh total asset terhadap tingkat disclosure laporan keuangan. $\mathrm{Hal}$ ini menunjukkan bahwa $\mathrm{H} 4$ ditolak.

Hasil analisis diperoleh Fhitung = 1,088 dengan $p=0,376$, sedangkan Ftabel adalah sebesar 2,61. Dalam penelitian ini uji $F$ mendapatkan hasil bahwa variabel likuiditas, leverage, profitabilitas dan total asset tidak pengaruh terhadap tingkat disclosure laporan keuangan.

\section{Pembahasan}

Hasil penelitian menunjukkan bahwa likuiditas yang diukur melalui current ratio tidak berpengaruh terhadap pengungkapan keuangan perusahaan. Artinya tinggi rendahnya current ratio perusahaan tidak mempengaruhi manajemen dalam mengungkapkan informasi di laporan keuangan.

Kemampuan perusahaan dalam mengelola asset perusahaan harus diungkapkan kepada publik secara penuh, baik perusahaan yang tingkat likuiditasnya rendah maupun tinggi. Semakin tinggi likuiditas perusahaan tidak semakin tinggi tingkat kelengkapan pengungkapan laporan tahunan. Konsisten dengan hasil penelitian sebelumnya yang dilakukan oleh Santioso dan Yenny (2012) yang membuktikan bahwa hanya ukuran perusahaan yang mempengaruhi pengungkapan kelengkapan laporan keuangan.

Hasil penelitian pada hipotesis kedua, yaitu rasio leverage tidak berpengaruh terhadap pengngunkapan laporan keuangan. Jadi debt to equity ratio tidak berpengaruh signifikan terhadap pengungkapan laporan keuangan. Hal ini menunjukkan debt to equity ratio dengan proksi tingkat debt to equity yang tinggi akan menunjukkan kuatnya kondisi keuangan perusahaan.

Perusahaan dengan tingkat debt to equity tinggi cenderung untuk tidak melakukan pengungkapan informasi yang lebih luas kepada pihak luar karena ingin semakin banyak tingkat modal yang dibiayai oleh utang akan menyebabkan niali perusahaan buruk. Hasil penelitian ini sejalan dengan hasil penelitian yang dilakukan oleh Sudarmadji dan Sularto (2007) yang menunjukkan rasio leverage tidak berpengaruh terhadap pengungkapan sukarela dimana dibuktikan bahwa leverage dengan proksi debt to equity ratio tidak berpengaruh terhadap pengungkapan laporan keuangan. Hasil dari penelitian ini membuktikan bahwa perusahaan akan cenderung mengungkapkan mengapa kondisi utang berada pada angka tersebut kepada publik, sehingga diharapkan investor mengetahui kondisi utang perusahaan secara lebih jelas.

Hipotesis ketiga dalam penelitian ini juga ditolak yaitu profitabilitas yang diukur dengan return on equity ratio tidak berpengaruh pada pengungkapan keuangan. Jadi return on equity ratio tidak berpengaruh signifikan terhadap pengungkapan laporan keuangan. Hasil penelitian ini sejalan dengan hasil penelitian yang dilakukan oleh Sudarmadji dan Sularto (2007) yang menunjukkan return on equity ratio tidak berpengaruh terhadap pengungkapan laporan keuangan.

Profitabilitas dengan proksi return on equity ratio tidak berpengaruh terhadap pengungkapan laporan keuangan. Hasil dari penelitian ini membuktikan bahwa Profitabilitas merupakan yang paling tinggi pada suatu entitas akan mendorong para 
manajer untuk memberikan informasi yang lebih terinci, karena para investor dan kreditur kebanyakan lebih menyukai entitas yang memiliki profitabilitas tinggi. Mereka menganggap bahwa profit yang tinggi pada suatu entitas mampu memberikan pengembalian investasi yang tinggi pula, sehingga semakin tinggi tingkat profitabilitas entitas maka semakin besar pengungkapan informasinya.

Hasil penelitian terkait ukuran perusahaan juga tidak berpengaruh terhadap pengungkapan laporan keuangan. Hal ini menunjukkan ukuran perusahaan dengan proksi total aset merupakan ukuran perusahaan menunjukkan besar kecilnya perusahaan yang dapat dilihat dari besar kecilnya total asset yang dimiliki perusahaan. Semakin besar total aset, maka semakin besar pula ukuran perusahaan. Hasil penelitian ini sejalan dengan hasil penelitian yang dilakukan oleh Sudarmadji dan Sularto (2007) yang menunjukkan total asset tidak berpengaruh terhadap pengungkapan laporan keuangan.

Hasil dari penelitian ini membuktikan bahwa tingkat disclosure laporan keuangan yang dilakukan oleh perusahaan tidak terkait dengan besar kecilnya ukuran perusahaan yang tercermin dalam total aktiva. Hal ini dikarenakan perusahaan yang besar belum tentu melakukan pengungkapan informasi laporan tahunan yang luas, hal ini disebabkan pertimbangan biaya pengungkapan informasi. Perusahaan harus efektif dan efisien dalam mengungkapkan informasi laporan tahunan.

Hasil penelitian ini juga sejalan dengan penelitian yang dilakukan oleh Sudarmadji dan Sularto (2007) yang sama menyatakan bahwa likuiditas, leverage, profitabilitas, dan ukuran perusahaan tidak pengaruh terhadap pengungkapan laporan keuangan. Selain berdasarkan hasil penelitian teori yang dijelaskan dalam Suwardjono (2012) menyatakan bahwa karakteristik pengungkapan dalam laporan keuangan dapat ditetapkan dengan menggunakan tiga pendekatan, yaitu karakteristik yang berhubungan dengan struktur, performa dan pasar. Struktur meliputi ukuran perusahaan dan kemampuan melunasi kewajibannya.

Performa mencakup likuiditas perusahaan dan keuntungannya, sedangkan pasar ditentukan oleh faktor-faktor yang bersifat kualitatif berupa tipe perusahaan, tipe auditor dan status perusahaan (go public atau tidak). Dengan karakteristik ini dapat membuktikan bahwa ukuran perusahaan dan kepemilikan menjadi faktor pendukung dalam tingkat disclosure laporan keuangan. Karakteristik perusahaan dapat berupa ukuran perusahaan (size), leverage, likuiditas, profitabilitas dan karakteristik lainnya.

\section{PENUTUP}

Penelitian ini bertujuan untuk menguji pengaruh likuiditas, leverage, profitabilitas dan ukuran perusahaan terhadap tingkat disclosure laporan keuangan. Dapat disimpulkan dengan hasil regresi bahwa likuiditas, leverage, profitabilitas dan ukuran perusahaan tidak mempunyai pengaruh terhadap tingkat disclosure laporan keuangan. ini berimplikasi bahwa tingkat disclosure laporan keuangan tidak terkait dengan performa perusahaan yang dilihat dari likuiditas, leverage, keuntungan perusahaan dan besar kecilnya aset perusahaan.

Likuiditas terhadap tingkat disclosure laporan keuangan. Berdasarkan hasil pengujian menunjukkan bahwa tidak terdapat pengaruh likuiditas terhadap tingkat disclosure laporan keuangan. Rasio leverage terhadap pengungkapan laporan keuangan. Berdasarkan hasil pengujian menunjukkan bahwa tidak terdapat pengaruh leverage terhadap tingkat disclosure laporan keuangan. Rasio profitabilitas terhadap pengungkapan laporan keuangan. Berdasarkan hasil pengujian menunjukkan bahwa tidak terdapat pengaruh profitabilitas terhadap tingkat disclosure laporan keuangan.

Pengaruh ukuran perusahaan terhadap pengungkapan laporan keuangan. 
Berdasarkan hasil pengujian menunjukkan bahwa tidak terdapat pengaruh ukuran perusahaan terhadap tingkat disclosure laporan keuangan. Hal ini memberikan implikasi bahwa disclosure laporan keuangan bagi perusahaan menerapkan sistem pengungkapan secara mandatory dan tidak lagi secara voluntary, sehingga tingkat pengungkapan laporan keuangan kurang relevan lagi jika dikaitkan dengan karakteristik perusahaan, misalnya likuiditas, leverage, profitabilitas dan ukuran perusahaan.

Bagi peneliti selanjutnya diharapkan menambahkan karakteristik perusahaan lainnya, misalnya: free cash flow, ROI, manajemen laba, kinerja perusahaan, dan sebagainya. Bagi peneliti selanjutnya diharapkan dapat memperpanjang periode pengamatan dan memperbesar jumlah sampel dalam penelitian sehingga hasil penelitiannya dapat menjadi lebih baik.

\section{REFERENSI}

Abd-Elsalam, O. H. (1999). The Introduction and Application of International Accounting Standards to Accounting Disclosure Regulations of a Capital Market in a Developing Country. Disertasi. Heriot-Watt University.

Albitar, K. (2015). Firm Characteristics, Governance Attributes and Corporate Voluntary Disclosure: A Study of Jordanian Listed Companies. International Business Research, 8(3), 110.

Daud, D. (2018). Pengaruh Karakteristik Perusahaan Terhadap Pengungkapan Corporate Social Responsibility (CSR) Pada Laporan Tahunan Di Indonesia. https://doi.org/10.17605/OSF.IO/QV93 $\mathrm{K}$.

Fitri, S. A. (2011). Analisis Tingkat Pengungkapan Laporan Keuangan Pemerintah Daerah (Studi Eksploratif pada Kabupaten/kota di Sumatera
Barat). Skripsi. Fakultas Ekonomi Universitas Andalas.

Hilmi, A. Z. (2010). Analisis Faktor-Faktor yang Mempengaruhi Tingkat Pengungkapan Laporan Keuangan Pemerintah Daerah Provinsi. Simposium Nasional Akuntansi XV, 2012.

Imhoff, E. (2003). Accounting Quality, Auditing And Corporate Governance. [online] SSRN. http://dx.doi.org/10.2139/ssrn.374380

Jensen, M. C., dan Meckling, W. H. (1976). Theory of the firm: Managerial behavior, agency costs and ownership structure. Journal of financial economics, 3(4), 305-360.

Kamil, A., dan Herusetya, A. (2012). Pengaruh karakteristik perusahaan terhadap luas pengungkapan kegiatan corporate social responsibility. Media Riset Akuntansi, 2(1).

Khasanah, N. L., dan Rahardjo, S. N. (2014). Pengaruh Karakteristik, Kompleksitas, Dan Temuan Audit Terhadap Tingkat Pengungkapan Laporan Keuangan Pemerintah Daerah. Diponegoro Journal Of Accounting, 3(2), 864-874.

Lesmana, S. I. (2010). Pengaruh Karakteristik Pemerintah Daerah terhadap Tingkat Pengungkapan Wajib di Indonesia. Skripsi. Universitas Sebelas Maret.

Patrick, P. A. (2007). The Determinants of Organizational Innovativeness: The Adoption Of GASB 34 In Pennsylvania Local Government. Pennsylvania: The Pennsylvania State University.

Santioso, L., dan Yenny, Y. (2012). FaktorFaktor Yang Mempengaruhi Kelengkapan Pengungkapan Wajib Dalam Laporan Keuangan Pada Perusahaan Manufaktur Yang Terdaftar Di BEl. The Winners, 13(2), 81-92.

Sembiring, H. (2012). Analisis Pengaruh Karakteristik Perusahaan terhadap Kelengkapan Pengungkapan dalam Laporan Tahunan Perusahaan 
Manufaktur yang Terdaftar di Bursa Efek Indonesia. Jurnal Mediasi, 4(01), 68-77.

Simanjuntak, B. H., dan Widiastuti, L. (2004). Faktor-Faktor Yang Mempengaruhi Kelengkapan Pengungkapan Laporan Keuangan Pada Perusahaan Manufaktur Yang Terdaftar Di Bursa Efek Jakarta. The Indonesian Journal of Accounting Research, 7(3)

Sriayu, G. A. P. W., dan Mimba, N. P. S. H. (2013). Pengaruh Karakteristik Perusahaan Terhadap Corporate Social Responsibility Disclosure. E-Jurnal Akuntansi, 326-344.

Sudarmadji, M,A., dan Sularto, L. (2007). Pengaruh ukuran perusahaan, profitabilitas, leverage, dan tipe kepemilikan perusahaan terhadap luas voluntary disclosure laporan keuangan tahunan. Seminar IImiah Nasional PESAT 2007 Lembaga Penelitian Universitas Gunadarma.

Suwardjono. (2012). Teori Akuntansi Perekayasaan Pelaporan Keuangan Edisi Ketiga. Yogyakarta: BPFE.
Suwito, E., dan Herawaty, A. (2005). Analisis pengaruh karakteristik perusahaan terhadap tindakan perataan laba yang dilakukan oleh perusahaan yang terdaftar di Bursa Efek Jakarta. Simposium Nasional Akuntansi VIII Solo, 15-16 September 2005.

Undang-Undang No. 21 Tahun 2013 Tentang Otoritas Jasa Keuangan

Yulianingtyas, Rukmita. R., Suhardjanto, D. (2011). Pengaruh Karakteristik Pemerintah Daerah terhadap Kepatuhan Pengungkapan Wajib dalam Laporan Keuangan Pemerintah Daerah (Studi Empiris pada Kabupaten/Kota di Indonesia). Jurnal Akuntansi \& Auditing, 8(1).

Zadeh, F. O., \& Eskandari, A. (2012). Firm Size As Company's Characteristic And Level Of Risk Disclosure: Review On Theories And Literatures. International Journal of Business and Social Science, 3(17). 